\title{
Adherence of rheumatoid polymorphonuclear cells (PMNs) to cultured endothelial cell monolayers
}

\author{
N J SHEEHAN, ${ }^{1}$ K A BROWN, ${ }^{1}$ J D PERRY ${ }^{2}$ R C CHASTY, \\ D A H YATES, AND D C DUMONDE
}

From the ${ }^{1}$ Department of Immunology, United Medical and Dental Schools, St Thomas's Campus, London; the ${ }^{2}$ Department of Rheumatology, The London Hospital; and the ${ }^{3}$ Department of Rheumatology, St Thomas's Hospital, London

SUMMARY Blood polymorphonuclear cells (PMNs) from 40 patients with rheumatoid arthritis (RA) and 40 normal subjects were incubated with confluent cultures of porcine aortic endothelium and their adherence assessed by either a microscopic or radiometric enumeration assay. There was no difference between the number of rheumatoid and control PMNs adhering. The synovial fluid PMNs from patients with RA were less adherent than their paired blood samples when autologous serum was present in the incubation medium and more adherent when serum was absent. Most of the RA sera tested inhibited the adhesion of normal PMNs, an effect that was not due to an increase in PMN aggregation. A similar inhibition was seen with sera obtained from patients with Felty's syndrome. These findings suggest that there is no intrinsic difference between the adhesiveness of rheumatoid PMNs and normal PMNs but that there are soluble factors present in RA serum which inhibit the attachment of normal PMNs to vascular endothelium.

Key words: rheumatoid arthritis, neutrophils, margination.

The continual influx of polymorphonuclear cells (PMNs) into the synovial fluid of rheumatoid joints is believed to be an important event in the pathogenesis of this disease. ${ }^{1}$ An essential prerequisite to PMN diapedesis into synovial tissue and subsequent entry into the synovial fluid is the margination of the cells to the endothelium of the local microvasculature. Although the factors that control PMN margination and transendothelial migration remain to be identified, specific glycoproteins on the surface of the PMNs, ${ }^{23}$ in addition to their secretory products, ${ }^{45}$ have been shown to promote adhesion to cultured endothelium. Thus the persistent emigration of PMNs into rheumatoid synovial fluid could arise from the circulation of PMNs already committed to enhanced adhesion to vascular endothelium. Previous studies have shown that rheumatoid PMNs express either similar ${ }^{6}$ or greater ${ }^{7}$ adhesion than normal PMNs. The adherence substrate in both these studies, however, was

Accepted for publication 11 August 1986.

Correspondence to Dr K A Brown, Department of Immunology, The Rayne Institute, St Thomas's Hospital, London SE1 7EH. nylon fibre, a material of questionable biological application.

It was the aim of this study to compare the adherence of RA and normal blood PMNs to cultured endothelium using a quantitative monolayer adhesion assay, and to determine if any apparent differences were the result of changes in the intrinsic property of the PMNs or of soluble factors present in serum.

\section{Patients and methods}

PATIENTS AND CONTROLS

Forty patients ( 22 women, 18 men) with classical or definite rheumatoid arthritis (RA) ${ }^{8}$ and 40 healthy control subjects ( 23 women, 17 men) were studied. Rheumatoid disease activity was graded as inactive, mild to moderately active, and very active according to a visual analogue pain scale. Duration of morning stiffness, patient's self assessment of severity, modified Ritchie index, physician's global assessment, and erythrocyte sedimentation rate were determined. 
PREPARATION OF PORCINE AORTIC

ENDOTHELIAL MONOLAYERS

Cultures of porcine aortic endothelial cells were prepared by a modification of the method of De Bono. ${ }^{9}$ Each aorta was washed through with phosphate buffered saline (PBS), filled with $10 \mathrm{ml}$ collagenase solution $(1 \mathrm{mg} / \mathrm{ml}$ PBS $)$, and incubated for $30 \mathrm{~min}$ at $37^{\circ} \mathrm{C}$. Thereafter, the collagenase solution was aspirated and the aorta washed out with medium (RPMI 1640 supplemented with $20 \%$ fetal calf serum (FCS), $2 \mathrm{mM}$ glutamine, $200 \mathrm{U} / \mathrm{ml}$ penicillin, and $100 \mathrm{U} / \mathrm{ml}$ streptomycin). The collagenase solution and the washings were pooled and centrifuged at $600 \mathrm{~g}$ for $10 \mathrm{~min}$. The endothelial cell pellet was resuspended in $10 \mathrm{ml}$ medium, added to a tissue culture flask, and incubated in a humidified $5 \% \mathrm{CO}_{2}$ incubator at $37^{\circ} \mathrm{C}$. When the endothelial cells had formed a confluent monolayer the medium was expelled and the cells treated with $2.5 \mathrm{ml}$ of $0.5 \%$ trypsin and $0.02 \%$ ethylenediaminetetraacetic acid (EDTA) in PBS for 3-5 min. The flask was gently shaken, trypsin digestion arrested by the addition of $2.5 \mathrm{ml}$ medium, and the contents together with $5 \mathrm{ml}$ of washing medium centrifuged at $600 \mathrm{~g}$ for $10 \mathrm{~min}$. The endothelial cells were resuspended in medium to $1 \times 10^{5}$ cells $/ \mathrm{ml}$ and $1 \mathrm{ml}$ plated onto a glass coverslip in each well of a Linbro multiwell plate. Confluent monolayers of endothelial cells were obtained after two days' culture at $37^{\circ} \mathrm{C}$ in a humidified $\mathrm{CO}_{2}$ incubator.

SEPARATION OF PMN

Twenty millilitres of heparinised blood $(10 \mathrm{U} / \mathrm{ml})$ were incubated with $2.5 \mathrm{ml}$ dextran solution (Dextraven 150) for $20 \mathrm{~min}$ at $37^{\circ} \mathrm{C}$. The leucocyte enriched plasma was removed and the cells pelleted. After washing and resuspending in $10 \mathrm{ml}$ EMEM (Eagle's minimum essential medium) the leucocytes were layered onto $9 \mathrm{ml}$ Lymphoprep (Nyegaard and Co, Norway) and centrifuged at $750 \mathrm{~g}$ for $20 \mathrm{~min}$. The pelleted PMNs were washed on three occasions with EMEM and adjusted to a final concentration of $2 \times 10^{6}$ cells $/ \mathrm{ml}$. PMN viability was $>98 \%$ and purity $>95 \%$.

\section{A DHERENCE ASSAYS}

PMN adherence to cultured endothelium was evaluated by two techniques based on the quantitative assay of Walther et al. ${ }^{10}$ The first entailed a visual count of the number of PMNs in nine high power microscopic fields and the second, a radiometric assay in which the PMNs were labelled with indium-111 ( ${ }^{111}$ In) oxine. Each experiment, which was performed in triplicate, consisted of monitoring the adherence of PMNs from one patient with RA and PMNs from a normal subject on endothelium derived from the same pig.
Microscopy assay (counts/nine high power fields) After aspiration of the nutrient medium from the endothelial monolayers $500 \mu \mathrm{l}\left(1 \times 10^{6}\right.$ cells $)$ of the PMN suspension were pipetted into each well together with $200 \mu \mathrm{l}$ autologous serum and $300 \mu \mathrm{l}$ EMEM, or $500 \mu \mathrm{l}$ EMEM alone. The PMNs were incubated with the monolayers for $60 \mathrm{~min}$ at $37^{\circ} \mathrm{C}$ $\left(100 \%\right.$ humidity, $\left.5 \% \mathrm{CO}_{2}\right)$. At the end of the incubation the endothelialised coverslips were removed and washed five times in PBS to remove any non-adherent PMNs. The preparations were fixed in methanol, mounted onto glass slides, and stained with Giemsa. PMN adherence was expressed as the total number of cells counted in nine random high power microscopic fields (9HPF).

\section{Radiometric assay}

The PMN suspension was pelleted and contaminating erythrocytes lysed by the addition of $0.83 \%$ ammonium chloride solution $\left(\mathrm{NH}_{4} \mathrm{Cl}\right)$ for $15 \mathrm{~min}$ at room temperature. After washing and resuspending the PMNs in PBS to $1 \times 10^{8}$ cells $/ \mathrm{ml}^{111}$ In (Amersham International) was added dropwise at an activity of $20 \mu \mathrm{Ci}(0.74 \mathrm{MBq}) / 10^{8}$ cells. The labelling reaction was stopped after $10 \mathrm{~min}$ at room temperature by $\overrightarrow{0}$ the addition of cold PBS. Excess ${ }^{111}$ In was remove $\$$ by centrifuging the cells through $50 \%$ FCS in PBS and washing once more in PBS. The radiolabellec PMNs were resuspended in EMEM at a concentration of $2 \times 10^{6} / \mathrm{ml}$. PMN viability remained over $95 \%$. One million of the labelled cells were added to each endothelialised coverslip as described in the microscopy method. After $60 \mathrm{~min}$ incubation at $37^{\circ} \mathrm{C}$ the medium containing nonadherent PMNs was carefully aspirated from each of the wells. The endothelialised coverslips were removed and transferred to vials. Gammacounts were performed on the coverslips and the aspirated medium to determine what percentage of the radioactivity was associated with the monolayers, this being proportional to the number of adherent PMNs.

STATISTICAL ANALYSIS

Normally distributed results were compared by Student's paired $t$ test.

\section{Results}

COMPARISON OF THE ADHERENCE OF RA AND CONTROL PMNS

Microscopy assay

Fig. 1a illustrates the comparative adherence of PMNs from 20 normal healthy subjects and $20:$ patients with RA. Regardless of the presence or absence of serum in the incubation medium there was no significant difference between the adherence 

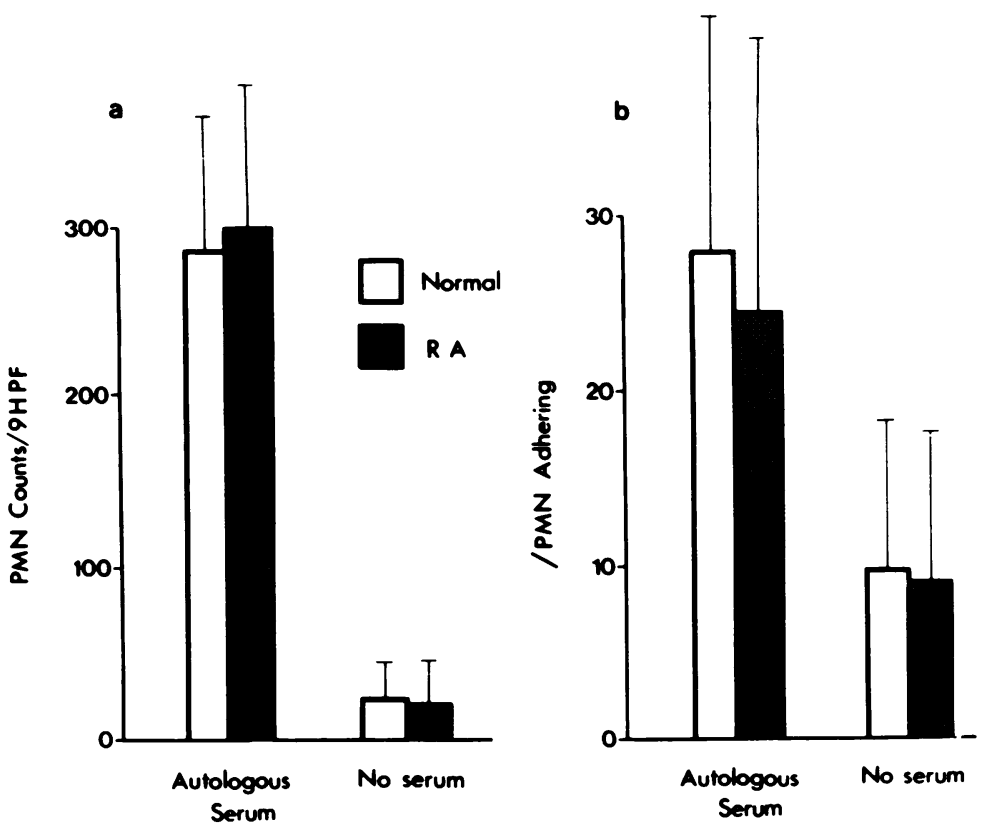

Fig. 1 Comparison of the adhesion of normal and rheumatoid PMNs to cultured endothelium using $(a)$ the microscopy assay and (b) the radiometric assay. Each histogram represents the mean $P M N$ response of 20 subjects and the vertical bars the standard deviation of the mean. The normal and rheumatoid subjects studied in (b) are different from those in (a). In each assay PMNs were either cultured in the absence of serum or in the presence of autologous serum.

of RA and normal PMNs. In the presence of autologous serum the mean number of adherent cells/9HPF was 283 (SD 82) for the normal PMN and $289(80)$ for the rheumatoid PMNs. In the absence of serum the corresponding figures were 24 (20) and 21 (21) respectively.

\section{Radiometric assay}

Study of an additional 20 normal subjects and 20 patients with RA showed that the percentage of PMNs which adhered to endothelium was similar within the two groups (Fig. 1b). The mean percentage of cells adhering to endothelium in the presence of autologous serum was 28 (16) for the normal PMNs and 25 (16) for the rheumatoid PMNs; in the absence of serum the percentage was 11 (9) and 9 (8) respectively.

Since both methods produced a similar result only one of them (microscopy assay) was employed for the remainder of the study.

COMPARATIVE ADHERENCE OF PAIRED

SAMPLES OF RA BLOOD AND SYNOVIAL

FLUID PMNS

Paired samples of blood and synovial fluid PMNs were obtained from six patients with RA. From Fig. 2 it can be seen that when $20 \%$ autologous serum was present in the incubation medium there was a mean $30 \%$ decrease $(p<0.001)$ in the adherence of the synovial fluid PMNs compared with the corresponding blood PMNs. In contrast, when the experiment was performed in the absence of serum the synovial fluid PMNs expressed an enhanced adherence $(p<0.05)$ compared with their paired blood PMNs.

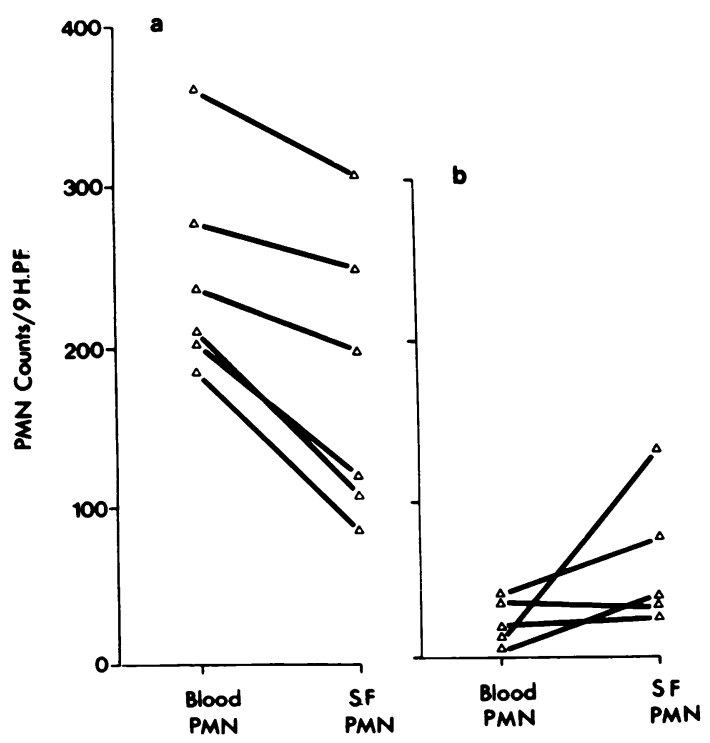

Fig. 2 Comparison of the attachment to cultured endothelium of PMNs isolated from paired samples of $R A$ blood and synovial fluid when autologous sera were either (a) present or (b) absent from the coculture. 


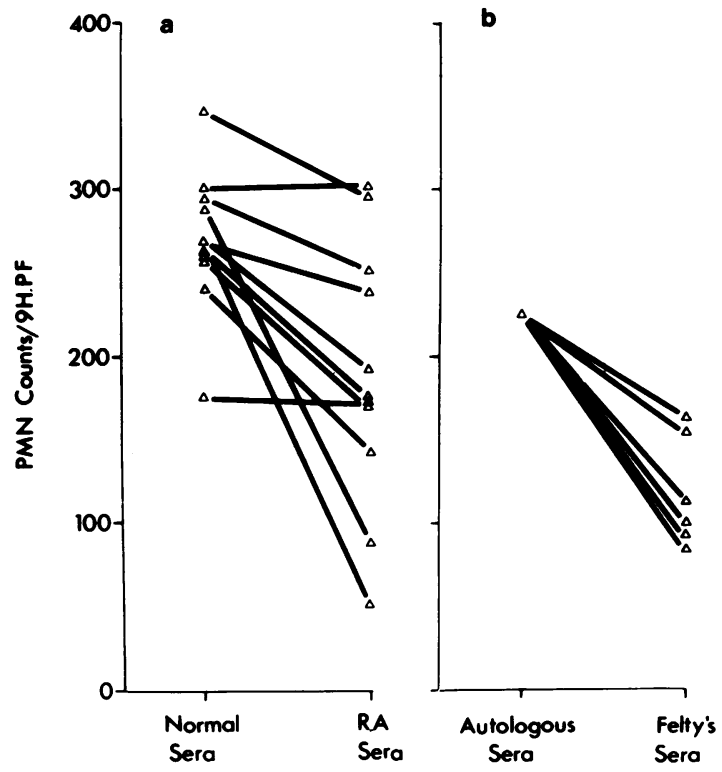

Fig. 3 Effect of RA and Felty's sera on the adhesion of normal PMNs. In (a) PMNs from each control subject were cocultured with endothelium in the presence of either $20 \%$ autologous or $20 \%$ RA sera. In (b) the adherence of PMNs from a normal subject, which were suspended in $20 \%$ autologous serum, was compared with the effect of six sera prepared from patients with Felty's syndrome.

EFFECT OF RHEUMATOID AND FELTY'S SERA ON THE ADHERENCE OF NORMAL PMNS Nine of the 11 RA sera tested decreased the adhesion of normal PMNs to endothelium (Fig. 3a). Overall, a mean adherence of 269 cells/9HPF for the normal PMNs when incubated with their autologous sera was reduced to 189 cells/9HPF after suspension in the RA sera $(p<0 \cdot 01)$. A similar decrease in adherence was seen when the PMNs of a control subject were cultured with sera from patients with Felty's syndrome (Fig. 3b). The six Felty's sera tested produced a mean of $47 \%$ inhibition of PMN adhesion.

\section{Discussion}

The demonstration that the number of PMNs from RA blood that attach to cultured endothelium is similar to that of PMNs from normal subjects is in agreement with a previous finding which used nylon fibre as the adherence substrate. ${ }^{6}$ When normal PMNs were incubated with endothelial cells in the presence of RA or Felty's serum, most of the sera tested impaired adherence. This effect could have been due to RA sera aggregating the PMNs, thus producing an apparent inhibition of adhesion. Such an explanation is unlikely as normal and RA sera $\frac{\square}{\omega}$. were later shown to possess similar activity in an aggregation assay. The finding that RA and Felty's $\overline{\bar{\omega}}$ sera inhibited the adhesion of normal PMNs dis- $\overline{0}$ agrees with the study of Hashimoto et al, who흐 reported that RA sera did not modify the adherence $\overline{\bar{s}}$ of normal PMNs to cultured endothelium, whereas $\overparen{\Phi}$ Felty's sera augmented their adhesion. ${ }^{11}$ At present we can offer no satisfactory explanation for these different results.

In view of the constant influx of PMNs into the $\overrightarrow{\vec{\omega}}$ rheumatoid synovial cavity ${ }^{12}$ we anticipated an increased adhesion of rheumatoid PMNs to the cultured endothelial cells. That such an effect was? not seen may have been owing to the collection of $\vec{\sigma}$ blood by venepuncture, which unavoidably selects PMNs from the circulating vascular pool rather than $\omega$ the marginating pool where the more adherent cells 음 may be found. Also, the inability to discriminate between the adhesion of normal and rheumatoid ${ }_{\mathcal{D}}^{\top}$ PMNs in a longitudinal study could arise from the biological variations that may be inherent in the leucocyte-endothelial cell assay. For example, those endothelial cell factors which are believed to be $\overrightarrow{0}$ important in mediating leucocyte adhesion, such $\stackrel{0}{6}$. the secretion of arachidonic acid metabolites ${ }^{13}$ or distribution of surface glycoproteins, may not uniformly expressed by endothelial monolayers prepared from different animals. In addition, the adherence specific determinants of PMNs may® require recognition by receptors which are optimally $\overrightarrow{\overrightarrow{2}}$ exposed by endothelial cells during specific stages of $\frac{}{3}$ culture.

Microelectrophoretic measurements performed in serum free medium have shown that the blood PMNs of patients with RA contain more cells of a low surface charge than the PMNs from normalo subjects. ${ }^{14}$ Moreover, cells of an even lower surface charge are further increased within the PMNs of rheumatoid synovial fluid (unpublished observa- $₹$ tions). Since leucocyte-endothelial cell interaction is음 thought to be governed in part by the extent of $\supset$ electrical repulsion ${ }^{15}$ these results suggest that $a$ 을. decrease in surface charge may explain why synovial $\bar{N}$ fluid PMNs, in the absence of serum, were more $\sigma$ adherent to cultured endothelium than their paired $\mathrm{O}$ PMNs, particularly as RA synovial fluid contains degranulated products of $\mathrm{PMNs}^{16}$ and activatedర components of complement, ${ }^{17}$ both of which reduce the negative surface charge of $\mathrm{PMNs}^{18}$ and $_{\bar{\Phi}}$ enhance their adhesion. ${ }^{4}{ }^{19}$ When autologous sera? were added to the coculture medium the synovial 0 fluid PMNs were less adherent than the paired blood우 sample, suggesting that the synovial fluid PMNs might be more susceptible than the blood PMNs to 
the action of any serum inhibitory factors. The identification of such factors and their possible relation to the pathogenesis of RA is described in the accompanying paper. ${ }^{20}$

This work was supported in part by a cooperative award from the Science and Engineering Research Council. NJS was in receipt of a St Thomas's Hospital Trustee Fellowship.

\section{References}

1 Weissmann G. Lysosomes and rheumatoid joint inflammation. Arthritis Rheum 1977: 20: 5193-204.

2 Arnaout M A, Pitt J, Cohen H J, Melamed J, Rosen F S, Collen H R. Deficiency of a granulocyte-membrane glycoprotein (GP150) in a boy with recurrent bacterial infections. $N$ Engl $J$ Med 1982; 306: 693-9.

3 Anderson D C, Schmalstieg F C, Arnaout M A. et al. Abnormalities of polymophonuclear leucocyte function associated with a heritable deficiency of high molecular weight surface glycoproteins (GP 138): common relationship to diminished cell adherence. J Clin Invest 1984; 74: 536-51.

4 Bockenstedt L K, Goetzl E J. Constituents of human neutrophils that mediate enhanced adherence to surfaces. Purification and identification as acidic proteins of the specific granules. J Clin Invest 1980; 65: 1372-81.

5 Oseas R, Hang H-H, Baehner R L, Boxer L A. Lactoferrin: promoter of polymorphonuclear adhesiveness. Blood 1981; 57: $939-45$.

6 Howe G B, Fordham J N, Brown K A, Currey H L F. Polymorphonuclear cell function in rheumatoid arthritis and in Felty's syndrome. Ann Rheum Dis 1981; 40: 370-5.

7 MacGregor R R. The effect of anti-inflammatory agents and inflammation on granulocyte adherence. $A m$ J Med 1976; 61: 597-607.

8 Ropes M W, Bennett G A, Cob S, Jacox R, Jesser R A. Revision of diagnostic criteria for rheumatoid arthritis. Bull Rheum Dis 1958; 9: 175-6.
9 De Bono D. Effects of cytotoxic sera on endothelium in vitro. Nature 1974: 252: 83-4.

10 Walther B T, Ohman R, Roseman S. A quantitative assay for intercellular adhesion. Proc Natl Acad Sci USA 1973; 70: 1569-73.

11 Hashimoto Y, Ziff M, Hurd E R. Increased endothelial cell adherence, aggregation, and superoxide generation by neutrophils incubated in systemic lupus erythematosus and Felty's syndrome sera. Arthritis Rheum 1982; 25: 1409-18.

12 Hollingsworth J W, Siegel E R, Creasey W A. Granulocyte survival in synovial exudate of patients with rheumatoid arthritis and other inflammatory joint diseases. Yale J Biol Med 1967; 39: 289-96.

13 Boxer L A, Allen J M, Schmidt M, Yoder M, Baehner R L. Inhibition of polymorphonuclear leukocyte adherence by prostacyclin. J Lab Clin Med 1980; 95: 672-8.

14 Brown K A, Goddard D H, Fordham J. Currey H L F, Holborow E J. Polymorphonuclear cell function in rheumatoid arthritis is related to surface charge. In: Preece A W, Light P A, eds. Cell electrophoresis in cancer and other clinical research. North Holland: Elsevier, 1981: 209-16.

15 Atherton A, Born G V R. Effects of neuraminidase and Nacetyl neuraminic acid on the adhesion of circulating granulocytes and platelets in venules. $J$ Physiol 1973; 234: 66-7.

16 Muirden K D. Lysosomal enzymes in synovial membrane in rheumatoid arthritis. Ann Rheum Dis 1972; 31: 265-71.

17 Ruddy S, Austen K F. The complement system in rheumatoid synovitis. I. An analysis of complement component activities in rheumatoid synovial fluids. Arthritis Rheum 1970; 13: 713-23.

18 Gallin J I, Durocher J R, Kaplan A P. Interaction of leucocyte chemotactic factors with the cell surface. I. Chemotactic-factor induced changes in human granulocyte surface charge. $J$ Clin Invest 1975; 55: 967-74.

19 Gallin J I. Degranulation stimuli decrease the negative surface charge and increase the adhesiveness of human neutrophils. J Clin Invest 1980; 65: 298-346.

20 Chasty R C, Brown K A, Sheehan N J, et al. Rheumatoid blood decreases the adherence of polymorphonuclear cells (PMNs) to cultured endothelium. Ann Rheum Dis 1987; 46: 98-103. 